UDC 372.851

Oleksandr Shkolnyi National Dragomanov Pedagogical University ORCID ID 0000-0002-3131-1915

Yurii Zakhariichenko National University "Kyiv-M ohyla Academy" ORCID ID 0000-0001-7436-3435 DOI 10.24139/2312-5993/2020.03-04/245-254

\title{
MODERN THEM ATIC PREPARATION FOR EIA IN MATHEMATICS IN UKRAINE: TEXT PROBLEMS AND MATHEMATICAL ANALYSIS
}

In modern realities, the relevance of research on thematic preparation for the IEA in mathematics is undeniable. Based on the author's experience of systematization and repetition of the school mathematics course in preparation for IEA, we propose to divide the entire mathematics course into 10 logical content blocks: "Numbers and expressions", "Functions", "Equations and systems of equations", "Inequalities and systems of inequalities", "Text problems", "Elements of mathematical analysis", "Plane geometry", "Space geometry", "Coordinates and vectors", "Elements of combinatorics and stochastics".

In this article, we provide thematic tests of the content blocks "Text problems" and "Elements of mathematical analysis", as well as answers to them. We also solve some of the basic tasks of these tests and give some methodological comments on these solutions. Traditionally, these topics cause significant difficulties for students in preparing for the test, so it is advisable for the teacher to pay special attention to them. We believe that a properly organized thematic systematization and repetition of the mathematics school course will allow students to successfully complete the IEA in mathematics and to help teachers achieve this success.

Key words: IEA in mathematics, SFA in mathematics, thematic preparation, educational achievements of students, thematic tests, basic tasks, text problems, mathematical analysis.

Introduction. External Independent Assessment (EIA) is now the main instrument of assessing the quality of mathematical preparation for Ukrainian senior school students. Also it is used for conducting the State Final Attestation (SFA) of academic achievements of graduates, as well as a tool for competitive selection of applicants to Ukrainian universities. Therefore, there is no doubt about the relevance and the need for research on different aspects of preparation for the EIA in mathematics.

One such aspect is the systematic and thematic repetition of the course of school mathematics. Based on our many years of experience in preparing for EIA, during this repetition we divide the whole mathematics course into 10 thematic blocks: "Numbers and expressions", "Functions", "Equations and systems of equations", "Inequalities and systems of inequalities", "Text problems", "Elements of mathematical analysis", "Geometry on the plane", "Geometry in the space", "Coordinates and vectors", "Elements of combinatorics and stochastics". 
This division allows constant repetition of the same material throughout the preparation process for the EIA. For example, different properties of elementary functions we can repeat during the studying of thematic blocks 2 , 3,4 , and 6 . This permits the teacher constantly to keep the student in a tone, when he or she would forget something important, but can't do this, because proposed thematic training system doesn't allow it.

Analysis of relevant research. The problem of preparing students for EIA in mathematics is systematically regarded in scientific and pedagogical publications in Ukraine. Permanently publish the results of their research in this area Valentyna Bevz, M ykhailo Burda, Hryhorii Bilianin, Olha Bilianina, Olha Vashulenko, Larysa Dvoretska, Oksana Yerhina, Oleksandr Ister, Vadym Karpik, Arkadii Merzliak, Yevhen Nelin, Victor Repeta, Oleksii Tomashchuk, Mykhailo Yakir and others. During the last 15 years, our author's team has been constantly working to provide methodological support for the process of preparation for the EIA in mathematics. The theory and methodology of assessing the academic achievement of senior school students in Ukraine is adduced in the monograph (Shkolnyi, 2015). For the training and systematization of the school mathematics course, we use the methodological set of books (Zakhariichenko et al., 2019a; 2019b). Previously, we had considered many different aspects of thematic preparation for independent testing in Ukraine, but since then the contingent of EIA participants has changed significantly, as well as the methodological views of our author's team on this problem are also progressed.

The aim of the article is to give some methodological advice to teachers and tutors regarding the thematic training of senior school students to EIA in mathematics. In particular, we present in this article two thematic tests related to the topics "Text problems" and "Elements of mathematical analysis", and also provide author's solution of the some basic tasks of these tests with methodological comments for them.

Research methods. In order to achieve this goal, we use in this paper some theoretical methods, such as an analysis of methodological literature on the research subject. Also, we apply some empirical methods: observation of the preparation process of the students during their studying on training courses for the EIA in mathematics and analysis of the results of their achievements. The research also used a set of methods of scientific cognition: a comparative analysis to find out different views on the problem and determine the direction of research; systematization and generalization for the formulation of conclusions and recommendations; generalization of author's pedagogical experience and observations.

Research results. Text problems have always been difficult to learn in school course of mathematics, because they required not only purely mathematical knowledge and skills, but also the skills of mathematical 
modeling of processes and phenomena of reality. Forming students' competences in this field is one of the most important tasks of the modern mathematics course in the school. Solving text problems enhances students' motivation to study mathematics, and these tasks show how important mathematical methods are in real life.

Mathematical analysis tasks have a different function - they develop the graduates' abstract thinking and help them feel the inner beauty of mathematics. However, the path to understanding this beauty lies in the hard work of the teacher and the student. The teacher should find clear examples of the tasks that reveal the essence of the basic concepts of mathematical analysis, and the student have to be persistent and diligent in performing the tasks selected by the teacher.

We believe that in preparing for the EIA, it is advisable to refrain from a variety of task forms in the repetition and systematization of the material of each topic, limiting only to open-ended tasks with full explanation, as they are the most effective for teaching mathematics and feedback. However, after finishing each of the 10 thematic blocks, it is natural to carry out a diagnostic thematic test in which to use all forms of test tasks inherent in the ElA math test.

Thematic test "Text problems".

Tasks 1-7 have five answer choices, only one of which is correct. Choose the correct answer, in your opinion.

1. The duration of the short film was 4 minutes. How many seconds did this movie last?

\begin{tabular}{|l|l|l|l|l|}
\hline A & B & C & D & E \\
\hline 400 & 40 & 240 & 24 & 2400 \\
\hline
\end{tabular}

2. The log $13 \mathrm{~m}$ long should be cut into two parts so that one part is $5 \mathrm{~m}$ shorter than the other. What length should be the smaller part of the cutted $\log$ ?

\begin{tabular}{|l|l|l|l|l|}
\hline A & B & C & D & E \\
\hline $5 \mathrm{~m}$ & $8 \mathrm{~m}$ & $2 \mathrm{~m}$ & $4 \mathrm{~m}$ & $9 \mathrm{~m}$ \\
\hline
\end{tabular}

3. To prepare 4 servings of cheese dumplings, you need a grams of cheese. How many grams of cheese are needed to prepare 12 such servings?

\begin{tabular}{|c|c|c|c|c|}
\hline A & B & C & D & E \\
\hline$\frac{3}{a}$ & $3 a$ & $\frac{a}{48}$ & $48 a$ & $\frac{a}{3}$ \\
\hline
\end{tabular}

4. 60 seats are reserved in the high-speed train, which is $\frac{5}{12}$ from the total number of seats in the train. How many seats in this train?

\begin{tabular}{|c|l|l|l|l|}
\hline A & B & C & D & E \\
\hline 25 & 119 & 288 & 35 & 144 \\
\hline
\end{tabular}

5. The cost of the first cake is $m \mathrm{UAH}$, and the second cake's cost is $30 \%$ less than the first. Determine the cost of the second cake (in UAH). 


\begin{tabular}{|l|l|l|l|l|}
\hline $\mathbf{A}$ & $\mathbf{B}$ & $\mathbf{C}$ & $\mathbf{D}$ & $\mathbf{E}$ \\
\hline $0,7 m$ & $m-30$ & $1,3 m$ & $m+30$ & $0,3 m$ \\
\hline
\end{tabular}

6. Only pencils and pens in the 4:1 ratio, respectively, are on the table. Specify a number that can represent the total number of items on this table.

\begin{tabular}{|c|c|c|c|c|}
\hline A & B & C & D & E \\
\hline 14 & 41 & 36 & 15 & 27 \\
\hline
\end{tabular}

7. Mary for 4 hours drove $36 \mathrm{~km}$. What distance will a girl travel in 3 hours, if she moves at the same speed?

\begin{tabular}{|l|l|l|l|l|}
\hline A & B & C & D & E \\
\hline $48 \mathrm{~km}$ & $144 \mathrm{~km}$ & $27 \mathrm{~km}$ & $9 \mathrm{~km}$ & $12 \mathrm{~km}$ \\
\hline
\end{tabular}

In the task 8 for each of the three rows of data marked with numbers, select the one correct, in your opinion, variant marked with a letter.

8. Match the beginning of the sentence $(1-3)$ and its end $(A-E)$ so that the correct statement will be formed.

Beginning of the sentence

1 Number 513

2 Number 109

End of the sentence

3 Number 344

A is simple number.

B is even number.

C is divided into 5 without a rest.

D is divided into 7 without a rest.

E is divided into 9 without a rest. or integer.

Solve tasks 9-11. Record the numeric answers you received in decimal

9. During the motorcycle show, two motorcyclists started to line up at the same time towards each other at constant speeds of $20 \mathrm{mps}$ and $16 \mathrm{mps}$.

1) How many meters in the first 4 seconds of movement did a motorcyclist pass, whose speed was slower?

2) Calculate the distance (in meters) that was between the motorcyclists at the time they started their traffic, if known that they met after 5 seconds.

10. The first tap fills the mineral water bath for 10 minutes, and the second tap fills it for 15 minutes. In what time (in minutes) will these two taps fill the bath, working together?

11. During the day, the tourist group made two crossings - flat $(9 \mathrm{~km}$ long) and mountainous ( $5 \mathrm{~km}$ long). During the flat transition, the group moved at a constant speed of $x \mathrm{~km}$ per hour, and during the mountain, it decreased that speed by $2 \mathrm{~km}$ per hour. Find out $x$, if you know that the total movement time of the group was 4 hours.

Solve the task 12. Write down sequential logical actions and explanations of all stages of task solving, make reference to the mathematical facts from which one or another statement follows. If necessary, illustrate the task solving with drawings, graphs, etc.

12. There are two solutions of the same acid, the concentration of acid in the first solution is $40 \%$ and in the second - is $10 \%$. 
1) M ix 300 grams of the first solution and 200 grams of the second. Find the concentration of acid in the resulting mixture.

2) How many grams of water should be added to 150 grams of the first solution so that the acid concentration in it becomes the same as in the second solution?

3) In what ratio (the weight of the first solution to the weight of the second solution) do you need to mix the two solutions to obtain the solution with $22.5 \%$ acid concentration?

Answers to the test "Text problems"

\begin{tabular}{|l|l|l|l|l|l|l|l|l|l|l|}
\hline $\mathbf{1}$ & $\mathbf{2}$ & $\mathbf{3}$ & $\mathbf{4}$ & $\mathbf{5}$ & $\mathbf{6}$ & $\mathbf{7}$ & $\mathbf{8}$ & $\mathbf{9}$ & $\mathbf{1 0}$ & $\mathbf{1 1}$ \\
\hline $\mathrm{C}$ & $\mathrm{D}$ & $\mathrm{B}$ & $\mathrm{E}$ & $\mathrm{A}$ & $\mathrm{D}$ & $\mathrm{C}$ & $\mathbf{1 - \mathrm { E } , 2 - \mathrm { A } , 3 - \mathrm { B }}$ & 1) $64 ; 2) 180$ & 6 & 4,5 \\
\hline
\end{tabular}

12. 1) $28 \%$, 2) 450 gram, 3) 5:7.

\section{Solutions and comments to tasks of test "Text problems".}

Task 5 (term of the task see above). Solution. To find the percentage of the number, you need to transfer that percentage into fractions and then multiply that fraction by a given number. Therefore, the discount for the second cake is equal to $0,3 \cdot \mathrm{m}$. Then the price of the second cake with a discount is equal to $m-0,3 m=0,7 m$ and the correct answer is $\mathbf{A}$.

Comment. One can solve this problem in another way. Let the price of the first cake be $100 \%$. Then the price of the second cake will be $100 \%-30 \%$ $=70 \%$ of the first cake price. Further, according to the rule given above, we have that the price of the second cake is $0,7 \mathrm{~m}$.

Different ways of solving show the student that almost any practical task has many alternative ways of getting the needed result. This contributes to the formation of an adequate outlook of the children and leads to a constant search for alternative solutions in different situations in their own life. In addition, the rule of finding the percentage of a number, unlike the method of using proportions, is simple and straightforward, and this rule works better in situations where the condition contains not a specific number but a parameter.

Task 11 (term of the task see above). Solution. According to the task term, the time of flat and mountain transitions are $\frac{9}{x}$ hours and $\frac{5}{x-2}$ hours respectively. Because the total time for the whole trip was 4 hours, we obtain the equation $\frac{9}{x}+\frac{5}{x-2}=4$. After solving of this equation, we will have $x_{1}=4,5$ and $x_{2}=1$. Obviously, the second solution does not satisfy the task term and the answer is $\mathbf{4 , 5}$.

Comment. The solution of this problem illustrates well all the steps of the mathematical modeling process. First, you need to separate the essential data from the irrelevant ones and make an equation that is a mathematical model of the practical problem. The condition of the task gives a little hint to the student exactly how to make this equation, because the variable whose value is to be 
found is already present in it. Next, you need to solve the mathematical problem correctly, that is, get the root equations. Finally, at the last stage, the student have to determine, which solutions of the mathematical problem will be the solutions of the practical problem and which do not satisfy its condition. The presence of such tasks enriches children, allows to develop their thinking and to form practical skills in the real world.

Thematic test "Elements of mathematical analysis".

Tasks 1-7 have five answer choices, only one of which is correct. Choose the correct answer, in your opinion.

1. Geometric progression $\left(b_{n}\right)$ is given by the formula $b_{n}=4 \cdot 3^{n-1}$. Calculate $b_{3}$.

\begin{tabular}{|c|l|l|l|l|}
\hline A & B & C & D & E \\
\hline$\frac{4}{3}$ & 4 & 12 & 13 & 36 \\
\hline
\end{tabular}

2. The first and second members of the geometric progression are 12 and 3 respectively. Calculate denominator $q$ of this progression.

\begin{tabular}{|l|l|l|l|l|}
\hline A & B & C & D & E \\
\hline 0,25 & -9 & 6 & 9 & 4 \\
\hline
\end{tabular}

3. Calculate the seventh term of the arithmetic progression, if the sum of the first 6 terms and first 7 terms of it are $S_{6}=22$ and $S_{7}=-4$ respectively.

\begin{tabular}{|l|l|l|l|l|}
\hline A & B & C & D & E \\
\hline 18 & $-\frac{11}{2}$ & -26 & $-\frac{2}{11}$ & 26 \\
\hline
\end{tabular}

4. Find the derivative of the function $y=4-\cos x$.

\begin{tabular}{|l|l|l|l|l|}
\hline A & B & C & D & E \\
\hline$y^{\prime}=-\sin x$ & $y^{\prime}=\sin x$ & $y^{\prime}=4 x-\sin x$ & $y^{\prime}=-\cos x$ & $y^{\prime}=4 x+\sin x$ \\
\hline
\end{tabular}

5. The figure shows a fragment of the function graph $y=f(x)$. Specify the number that can be the value of $f^{\prime}(3)$.

\begin{tabular}{|l|l|l|l|l|}
\hline A & B & C & D & E \\
\hline-3 & 0 & $-0,4$ & 0,7 & $-\sqrt{2}$ \\
\hline
\end{tabular}

6 . It is known that $f^{\prime}(x)=x(x-4)$. Specify the interval at which the function $y=f(x)$ is decreased.

\begin{tabular}{|l|l|l|l|l|}
\hline A & B & C & D & E \\
\hline$(-\infty ;-3)$ & $(5 ;+\infty)$ & $(-2 ; 2)$ & $(3 ; 7)$ & $(1 ; 3)$ \\
\hline
\end{tabular}

7. Calculate the integral $\int_{0}^{1} \sqrt[3]{x} d x$. 


\begin{tabular}{|c|c|c|c|c|}
\hline A & B & C & D & E \\
\hline$\frac{4}{3}$ & $\frac{1}{3}$ & $\frac{3}{4}$ & $\frac{1}{4}$ & 1 \\
\hline
\end{tabular}

In the task 8 for each of the three rows of data marked with numbers, select the one correct, in your opinion, variant marked with a letter.

8. The figure shows a graph of a linear function $y=f(x)$. M atch the beginning of the sentence $(1-3)$ and its end $(A-E)$ so that the correct statement will be formed.

Beginning of the sentence

1 The value of $f(4)$ equals to

2 The value of $f^{\prime}(0)$ equals to

3 The value of $\int_{0}^{2} f(x) d x$ equals to

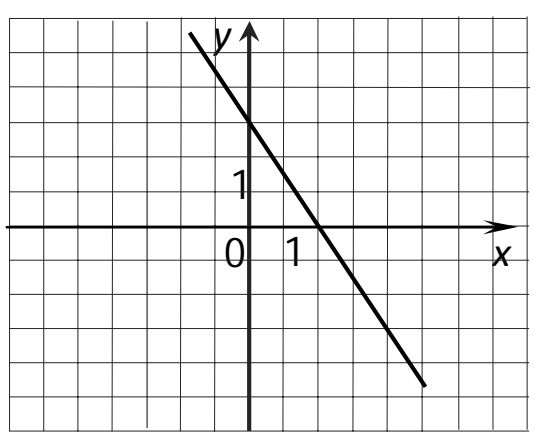

End of the sentence
A 3
B 0
C $-\frac{2}{3}$
D $-\frac{3}{2}$
E -3

Solve tasks 9-11. Record the numeric answers you received in decimal or integer.

9. The first three elements of an arithmetic progression $\left(a_{n}\right)$ have the form: $a_{1}=2 ; a_{2}=x ; a_{3}=3 x+20$. Find: 1 ) the value of $x ; 2$ ) the fourth element of this progression.

10. It is known that $f(x)$ is odd and $\int_{-3}^{0} f(x) d x=15$. Calculate $\int_{-3}^{3}(5+f(x)) d x$

11. It is known that $x+y=10$. Find the smallest value of the expression $x^{2}+y^{2}$.

Solve the task 12. Write down sequential logical actions and explanations of all stages of task solving, make reference to the mathematical facts from which one or another statement follows. If necessary, illustrate the task solving with drawings, graphs, etc.

12. Let $f(x)=x^{3}-6 x^{2}+50$. Find:

1 ) the largest and smallest value of the function $f(x)$ on the segment $[-2 ; 5]$; 
2) the equation of the tangent drawn to the graph $f(x)$ at the point whose abscissa $x_{0}=1$;

3) the area of curved trapezoid bounded by the graph $f(x)$, abscissa axis and straight lines $x=1$ and $x=3$.

Answers to test «Elements of mathematical analysis»

\begin{tabular}{|l|l|l|l|l|l|l|l|l|l|l|}
\hline $\mathbf{1}$ & $\mathbf{2}$ & $\mathbf{3}$ & $\mathbf{4}$ & $\mathbf{5}$ & $\mathbf{6}$ & $\mathbf{7}$ & $\mathbf{8}$ & $\mathbf{9}$ & $\mathbf{1 0}$ & $\mathbf{1 1}$ \\
\hline $\mathrm{E}$ & $\mathrm{A}$ & $\mathrm{C}$ & $\mathrm{B}$ & $\mathrm{D}$ & $\mathrm{E}$ & $\mathrm{C}$ & $\begin{array}{l}1-\mathrm{E}, 2-\mathrm{D}, 3- \\
\mathrm{A}\end{array}$ & $\begin{array}{l}1)-22 ; 2) \\
70\end{array}$ & 30 & 50 \\
\hline
\end{tabular}

12. 1) $f_{\min }=18, f_{\max }=50$, 2) $y=-9 x+54$; 3) 68 .

analysis".

Solutions and comments to tasks of test "Elements of mathematical

Task 5 (term of the task see above). Solution. Since the function shown in the figure increases at a point $x_{0}=3$, then by the well-known theorem of differential calculus the derivative $f^{\prime}(3)>0$ and the correct answer can be $\mathbf{D}$ only.

Comment. This problem can be solved in another way using the geometric content of the derivative. In fact, by the figure, the tangent to the function graph $f(x)$ in the point $x_{0}=3$ forms a sharp angle with the positive direction of the abscissa axis. The tangent of this angle is obviously a positive number.

This task does not contain cumbersome technical calculations, it aims at understanding the essence of the concept of the derivative. Unfortunately, such problems cause difficulties for those students, who pay attention only to the technique of calculating derivatives and the use of known algorithms. Therefore, the teacher should emphasize that the good differentiation technique does not guarantee proper mastery of the subject matter.

Task 9 (term of the task see above). Solution. 1) Using the criterion of arithmetic progression, we get that $a_{2}=\frac{a_{1}+a_{3}}{2}$, whereof $x=\frac{2+3 x+20}{2}$ and $x=-22$.

2) Find the difference of this progression: $d=a_{2}-a_{1}=-22-2=-24$. Thus, $a_{4}=a_{1}+3 d=2+3 \cdot(-24)=-70$.

Comment. The second part of this task can also be solved using the arithmetic progression criterion, but we think that during the repetition we need to use so many formulas associated with the topic as possible. The above given solution of item 2) allows to repeat the definition of the difference of arithmetic progression and the formula of its general term.

During considering arithmetic and geometric progressions it is also important to emphasize that their names originate precisely from the characteristic properties (criteria) of these sequences. Indeed, each element of the arithmetic (geometric) progression, starting with the second, is the arithmetic (geometric) mean of the two adjacent elements of that progression. Such an emphasis contributes to the growth of cognitive interest in children, 
both to the mentioned progressions and to other sequences that have numerous practical applications.

Conclusions. Text problems and mathematical analysis tasks have a significant worldview in the learning process. They contribute to the formation of practical competences and development of abstract and critical thinking of the children. That is why the EIA test in mathematics contains tasks on these topics. During preparation for the test, the teacher has an opportunity to pay attention to such tasks, further emphasizing their importance.

We believe that well-organized thematic preparation for external independent assessment in mathematics will allow teachers to cope with the problems encountered by students in the systematization and repetition of the school mathematics course. We sincerely hope that the suggested methodological tips will be useful for all experts involved in this process. In future publications, we plan to continue to look at the repetition features for all of the above thematic blocks, as well as provide the summary test for each such block with solutions to the basic tasks and with providing of methodological comments to them.

\section{REFERENCES}

Shkolnyi, O. V. (2015). The basic of theory and methodology of educational achievements for senior school students in Ukraine. Kyiv: Dragomanov NPU Publishing.

Zakhariichenko, Yu. O., Shkolnyi, O. V., Zakhariichenko, L. I., Shkolna, O. V. (2019a). Full course of math in tests. Encyclopedia of test items. In 2 parts. Part 1. Tasks of different levels. 9-th edition. Kharkiv: Ranok.

Zakhariichenko, Yu. O., Shkolnyi, O. V., Zakhariichenko, L. I., Shkolna, O. V. (2019b). Full course of math in tests. Encyclopedia of test items. In 2 parts. Part 2. Theoretical information. Thematic and final tests. 3-rd edition. Kharkiv: Ranok.

\section{АНОТАЦІЯ}

Школьний Олександр, Захарійченко Юрій. Сучасна тематична підготовка до зНО з математики в Україні: текстові задачі і математичний аналіз.

у сучасних умовах актуальність досліджень, присвячених тематичній підготовці до зно з математики, не викликає сумнівів. Спираючись на авторський досвід систематизації й повторення шкільного курсу математики під час підготовки до зНО, ми пропонуємо поділ всього курсу математики на 10 логічних змістових блоків: «Числа і вирази», «Функції», «Рівняння та системи рівнянь», «Нерівності та системи нерівностей», «Текстові задачі», «Елементи математичного аналізу», «Планіметрія», «Стереометрія», «Координати i вектори», «Елементи комбінаторики і стохастики».

у цій статті ми наводимо тематичні тести змістових блоків «Текстові задачі» та «Елементи математичного аналізу», а також відповіді до них. Також ми розв'язуємо окремі базові задачі иих тестів та подаємо методичні коментарі до иих розв'язань. Традиційно саме наведені теми викликають значні труднощі в учнів під час підготовки до тестування, тому вчителю доцільно звернути на них особливу увагу. Ми вважаємо, що належним чином організована тематична систематизація й повторення шкільного курсу математики дозволить учням успішно скласти зНО з математики, а вчителям сприяти досягненню цього успіху. 
Ключові слова. ЗНО з математики, ДПА з математики, тематична підготовка, навчальні досягнення учнів, тематичні тести, базові задачі, текстові задачі, математичний аналіз.

\section{PEЗЮМЕ}

Школьный Александр, Захарийченко Юрий. Современная тематическая подготовка к ВНО по математике в Украине: текстовые задачи, математический анализ.

В современных условиях актуальность исследований, посвященных тематической подготовке к ВНО по математике, не вызывает сомнений. Опираясь на авторский опыт систематизации и повторения школьного курса математики при подготовке к ВНО, мы предлагаем разделение всего курса математики на 10 логических смысловых блоков: «Числа и выражения», «Функции», «Уравнения и системы уравнений», «Неравенства и системы неравенств», «Текстовые задачи», "Элементы математического анализа», «Планиметрия», «Стереометрия», «Координаты и векторы», «Элементы комбинаторики и стохастики».

Ключевые слова: ВНО по математике, ГИА по математике, тематическая подготовка, учебные достижения учащихся, тематические тесты, базовые задачи, текстовые задачи, математический анализ. 